\title{
EFFECT OF DEFORESTATION OF DIFFERENT GENESIS ON SPATIAL VARIABILITY OF NITRATE CONCENTRATION IN STREAM WATER IN THE TATRA NATIONAL PARK
}

\author{
Miroslaw Żelazny ${ }^{1}$, Marta Pufelska ${ }^{1}$, Monika Sajdak ${ }^{1}$, Łukasz Jelonkiewicz ${ }^{1}$, \\ Marcin Bukowski \\ ${ }^{1}$ Institute of Geography and Spatial Management, Jagiellonian University in Kraków, ul. Gronostajowa 7, 30-387 Kraków \\ ${ }^{2}$ Tatra National Park, Kuźnice 1, 34-500 Zakopane
}

\section{ABSTRACT}

Aim of study

The aim of the study was to determine the effect of deforestation of different genesis on the spatial differentiation of $\mathrm{NO}_{3}^{-}$concentration in the Polish Tatras.

\begin{abstract}
Materials and methods
In 2018, 728 water samples were collected in the Tatras by hydrological and chemical survey. In the Hydrological and Chemical Laboratory of IGiGP UJ, ion chromatography determined: $\mathrm{Ca}^{2+}, \mathrm{Mg}^{2+}, \mathrm{Na}^{+}, \mathrm{K}^{+}, \mathrm{HCO}_{3}^{-}$, $\mathrm{SO}_{4}^{2-}, \mathrm{Cl}^{-}, \mathrm{NO}_{3}^{-}, \mathrm{NO}_{2}^{-}, \mathrm{NH}_{4}^{+}, \mathrm{PO}_{4}^{3-}, \mathrm{Li}^{+}, \mathrm{F}^{-}$and $\mathrm{Br}^{-}$. Nitrates from 1719 water samples were analyzed in order to compare their current concentration to the period of 2007-09 $(\mathrm{n}=991$ water samples). The Tatras were divided into 13 areas.
\end{abstract}

\begin{abstract}
Results and conclusions
The chemical composition of waters draining both forested and deforested Tatra slopes showed that in the decade from 2007-09 to 2018 the concentrations of $\mathrm{NO}_{3}$ increased rapidly. In 2018, an average $\mathrm{NO}_{3}^{-}$concentration expressed by median was higher by as much as $60.2 \%$, rising from 1.76 to $2.82 \mathrm{mg} \cdot \mathrm{dm}^{-3}$. The fluctuations in maximum concentrations were more pronounced, because their multiple increase occurred in five valleys, with the largest in: The Lejowa (by $348.2 \%$ ) from 4.75 to $21.30 \mathrm{mg} \cdot \mathrm{dm}^{-3}$; over double: Małej Łąki, Za Bramką and in Suchy Żleb; Kościeliska with Staników Żleb; Strążyska, Ku Dziurze and Spadowiec and Olczyska. Only in two areas the concentrations were lower. Comparison of the average $\mathrm{NO}_{3}^{-}$concentration in Tatra waters has definitely proven its higher levels than in other regions of Poland in forested catchments or agricultural catchments, with the exception of catchments with intensive agricultural activities. Diverse genesis of deforestation result in strong mosaic-like spatial differentiation of the $\mathrm{NO}_{3}^{-}$concentration. In waters draining the slopes deforested due to windfall, there is a concentration of $\mathrm{NO}_{3}^{-}>10 \mathrm{mg} \cdot \mathrm{dm}^{-3}$, which can potentially cause an unfavorable phenomenon of eutrophication of waters, however, it has a natural cause.
\end{abstract}

Keywords: Tatra Mountains, waters, $\mathrm{NO}_{3}^{-}$concentration, deforestation, eutrophication 


\section{INTRODUCTION}

Hydrological and chemical research are carried out in catchments with diverse anthropopressure, and forest ecosystems - due to the functions that forest performs in a natural environment - are a frequent subject of study. In the United States since the 1930s in the Coweeta catchment (North Carolina), and since the 1960s research related to the functioning of forest ecosystems take place in the Hubbard Brook basin (New Hempshire). The experiments run there involved changing a forest structure from multi-species to coniferous, as well as clearing the forest area with various techniques and observing the reaction of water levels (Swank et al., 1988). G. E. Likens (2013) presented 50 years of hydrological and chemical research in the experimental catchment of Hubbard Brook. This is a comprehensive study on ion circulation in the catchment. In Poland in the catchments of the Western Sudetes, for over a decade a long-term deforestation has been observed. One of the reasons is the impact of industrial immissions from Germany, the Czech Republic and Poland, from the so-called Black Triangle (Černy and Paces, 1995). The consequences of deforestation for the hydrological and chemical circulation of ions in the Sudetes catchment areas was determined (Pierzgalski et al., 2007, 2009). Existing research indicates that a deforestation of catchment leads to a change in the chemical composition of shallow groundwater circulation. Numerous studies prove that in the first few months after clearing trees begins the process of leaching of main ions and $\mathrm{NO}_{3}^{-}$from soil, which results in an increase in their concentration in river waters (Likens et al., 1969; Martin et al., 1986; Hornbeck et al, 1987; Houlton et al., 2003, Rothe and Mellert, 2004; Wang et al. 2006; Pierzgalski et al., 2009). The process of strong ion leaching usually lasts several years and depends on the level of deforestation of a catchment (Siemion et al., 2011). Lack of biogenes uptake (e.g. $\mathrm{NO}_{3}^{-}$) by a trees causes an increase of their concentration in both soil and river waters (Houlton et al., 2003). According to Eshleman et al. (1998) weakening of a trees following the invasion of insects contributes to a decrease in the uptake of nutrients by a forest and an increase in their concentrations in river waters. During surveys in 2007-2009 physical characteristics and chemical composition of ground- water (spring) and stream water were determined. It has been noticed that the main nutrients in waters is $\mathrm{NO}_{3}^{-}$, while $\mathrm{NH}_{4}^{+}, \mathrm{NO}_{2}^{-}$and $\mathrm{PO}_{4}^{3-}$ occur rarely. During the last decade, deforestation has been observed in the Tatra region. Particularly strong natural effects were caused by a foehn wind that in December 2013 deforested entire slopes, e.g. in the Kopki Kościeliskie area in the Kościeliska Valley and the Lejowa Valley. In the windfall area in the Kościeliska Valley, deforestation caused windthrow pits, representing $3.9 \%$ of the area (Strzyżowski et al., 2016). On average, $378 \mathrm{~m}^{3} \cdot \mathrm{ha}^{-1}$ of mineral-soil material (Strzyżowski et al., 2018) was dislocated in the Lejowa and Kościeliska Valleys in the tree stump windfall region. In addition to geomorphological changes, the change of slope covering affects the ion cycle and the spatial differentiation of the chemical composition of shallow groundwater circulation. The aim of research was to determine the impact of deforestation on the spatial variability of nitrate concentrations in the Tatra Mountains.

\section{METHODS}

Fieldworks on the chemical composition of waters in the Tatra National Park (TPN) were run twice according to the hydrological and chemical survey method. The first survey of the entire Polish Tatras $\left(211.6 \mathrm{~km}^{2}\right)$ was carried out in 2007-09 (MNiSW N $30508132 / 2824)$, and the second a decade later - in 2018 (project UJ, TPN: ZP/483/2018). During the survey in the 2007-2009 summer seasons, surface water and groundwater was collected from 1505 hydrological objects (Żelazny, 2012). For the following analysis, 991 were selected, so the interpretation included groundwater represented by springs found throughout the entire TPN and occassionaly small streams draining inaccessible areas. In the summer of 2018, 728 springs and streams were again surveyed, with particular regard to forested slopes called lower and higher montane zone. The chemical composition of waters was determined by ion chromatography (DIONEX 2000) main ions: calcium $\left(\mathrm{Ca}^{2+}\right)$, magnesium $\left(\mathrm{Mg}^{2+}\right)$, sodium $\left(\mathrm{Na}^{+}\right)$, potassium $\left(\mathrm{K}^{+}\right)$, bicarbonates $\left(\mathrm{HCO}_{3}^{-}\right)$, sulfates $\left(\mathrm{SO}_{4}^{2-}\right)$, chlorides $\left(\mathrm{Cl}^{-}\right)$; mineral forms of nitrogen: nitrates $\left(\mathrm{NO}_{3}^{-}\right)$, nitrites $\left(\mathrm{NO}_{2}^{-}\right)$, ammonium $\left(\mathrm{NH}_{4}^{+}\right)$and phosphates $\left(\mathrm{PO}_{4}^{3-}\right)$ and trace elements: lithium $\left(\mathrm{Li}^{+}\right)$, fluorides $\left(\mathrm{F}^{-}\right)$and bromides $\left(\mathrm{Br}^{-}\right)$. Usually the concen- 
tration of microelements, except for fluorides $\left(\mathrm{F}^{-}\right)$and biogenic compounds, represented by the mineral forms of nitrogen: nitrites $\left(\mathrm{NO}_{2}^{-}\right)$and ammonium $\left(\mathrm{NH}_{4}^{+}\right)$and orthophosphates $\left(\mathrm{PO}_{4}^{3-}\right)$, did not exceed the detection limit. For this reason, they were not interpreted. The detailed course of field hydrological and chemical survey from 2007-2009 and the description of the laboratory was discussed in the monograph (Spatiotemporal variability...) (Żelazny, 2012). In 2018, the same survey methods as in 2007-2009 were used. Influence of complex geological structure of the Polish part of Tatra Mountains is observed in strong differences in chemical composition of waters. Often the ion concentration distributions are asymmetrical, therefore, apart from the usually used statistics (arithmetic average, minimum (Min), maximum (Max)) the following positional measures were applied for the interpretation: quantiles $\left(\mathrm{Q}_{25 \%}\right.$ and $\left.\mathrm{Q}_{75 \%}\right)$; median $(\mathrm{Me})$, decile $\left(\mathrm{P}_{10 \%}\right.$ and $\mathrm{P}_{90 \%}$ ). The variability was characterized by the interquartile coefficient of variation $\left(\Psi=\left(\mathrm{Q}_{75}-\mathrm{Q}_{25}\right)\right.$ $\mathrm{Me}) * 100 \%$ ) and assessed on a 5-point scale: $<50 \%$ very low variability, $50-100 \%$ low, $100-150 \%$ average, $150-200 \%$ large and $>200 \%$ very large. In total, 1719 water samples were used for hydrochemical interpretation in both projects. The Tatra area is divided into 13 basic areas (see: Fig. 1) in relation to the main Tatra valleys.

\section{RESEARCH AREA}

The Tatra National Park (TPN) includes the only high mountain area in Poland, which at the same time is the highest mountain range in the entire Carpathian Mountains. In terms of geology and tectonics, the Tatra Mountains are extremely complex (Stupnicka, 1997). The southern, highest part of the massif is built

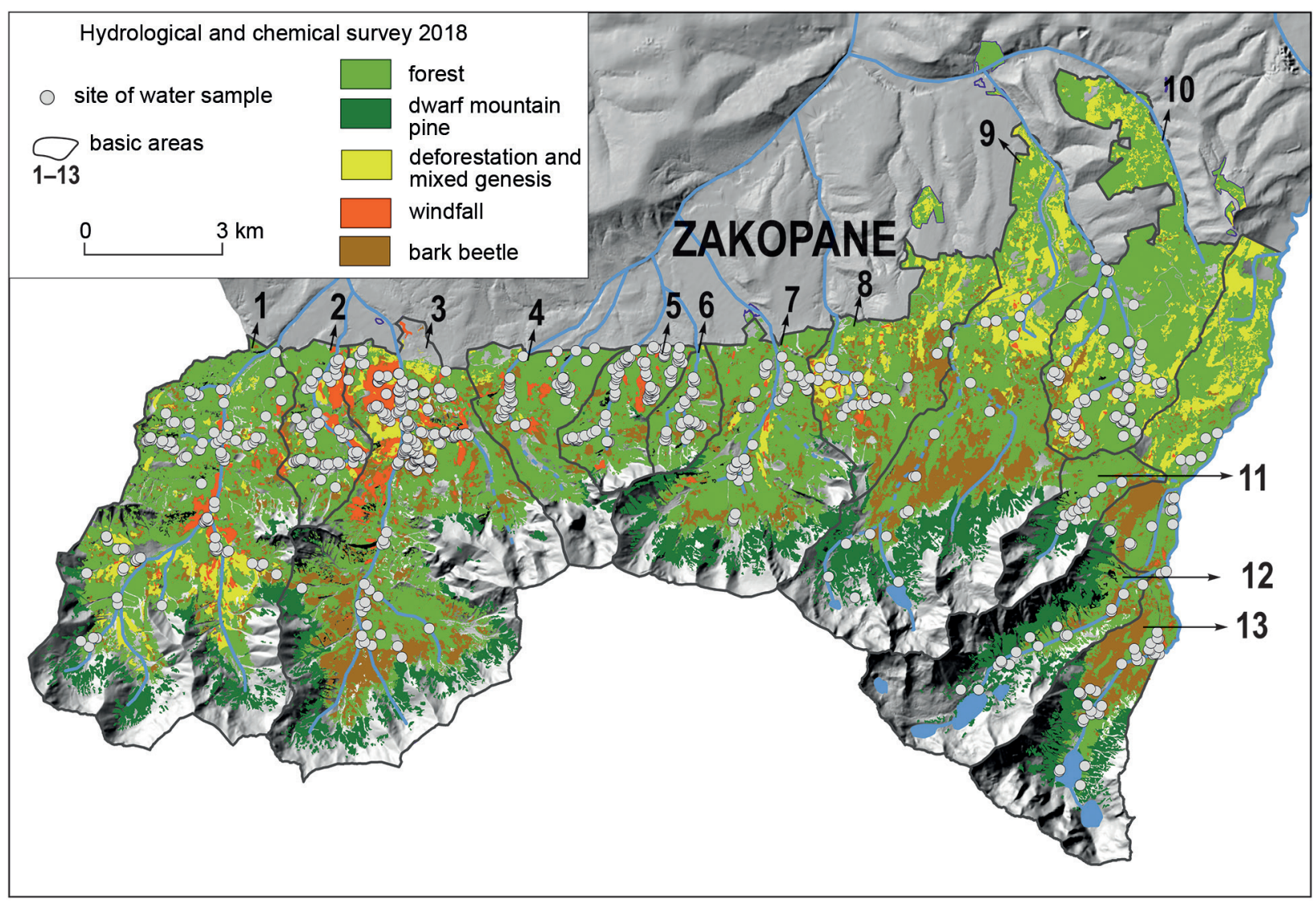

Fig. 1. Hydrological and chemical mapping 2018 
of metamorphic and igneous rocks, forming a crystalline core. From the north and west it is surrounded by Mesozoic sedimentary rocks, e.g. limestone, marl, dolomite, dolomite conglomerate, sandstone and shale. The Tatra Mountains have a distinct vegetation and climate zone (Hess, 1974; Radwańska-Paryska, 1974). The lowest (up to $1150 \mathrm{~m}$ a.s.1.) moderately cold zone (average annual air temperature: $+6^{\circ} \mathrm{C}-+4^{\circ} \mathrm{C}$ ) is covered by a mixed forest (beech, fir, spruce) on a redzinas soil and coniferous forest (fir, spruce) - on an acid ground (glacial moraines). The zone's natural vegetation was largely transformed in consequence of intensive felling (iron and paper industry) in the 19th century; currently most of the area is occupied by monoculture spruces (Fabijanowski and Dziewolski 1996). The cold zone $\left(+4^{\circ} \mathrm{C}-+2^{\circ} \mathrm{C}\right)$ with coniferous forest (spruce, larch, and limba above) occurs at an altitude of 1150-1550 m a.s.l. Above the upper forest border (1550-1850 $\mathrm{m}$ a.s.l.) there is a very cool zone $\left(+2^{\circ} \mathrm{C}-0^{\circ} \mathrm{C}\right)-$ the zone of dwarf mountain pine. Moderately cold zone $\left(0^{\circ} \mathrm{C}-2^{\circ} \mathrm{C}\right)$ ranges between an altitude of 1850 to $2250 \mathrm{~m}$ a.s.1., and is similar to the alpine zone (so-called high mountain meadows). Currently, the forests of the Polish Tatras are undergoing severe degradation, which is caused by various natural factors, including strong gradation of bark beetle and disastrous windfall from December 2013. Spatial differentiation of land cover with distinction of areas completely deforested due to windfall and bark beetle gradation is illustrated in Fig.1 and in Table 1. It is worth noting that $\sim 18 \%$ areas are deforested by a natural factors. Areas with the highest level of deforestation caused by windfall are: Lejowa Valley $(14.7 \%)$, Kościeliska-Staników Żleb (5.2\%), Strążyska-Ku Dziurze - Spadowiec (5.1\%), but it is worth mentioning that e.g. in the Kościeliska Valley in the Kopki Kościeliskie area windfall in 2013 almost completely deforested the catchment of Pośrednia Kopka (90\%). Whereas, the most serious bark beetle gradation is observed in the valleys: Olczyska (16.3\%), Kościeliska-Staników Żleb (13.7\%), Sucha Woda (13.0\%) and Rybi Potok $(12.3 \%)$. It should be emphasized that in all Tatra valleys, especially in the so-called lower and upper regiels, the collapse of the forest stands observed due to bark beetle gradation covers $9.1 \%$ of the TPN area.

\section{RESULTS AND DISCUSSION}

The chemical composition of Tatra waters obtained during the research in 2018 corresponds in regard to main ions to the characteristics given by Żelazny (2012, 2015). Lithology determines chemical composition to a larger degree than plant and climate zonation, which was considered in the latest regional-

Table 1. Land cover in valleys (\%).

\begin{tabular}{|c|c|c|c|c|c|c|c|c|c|c|c|c|c|c|}
\hline 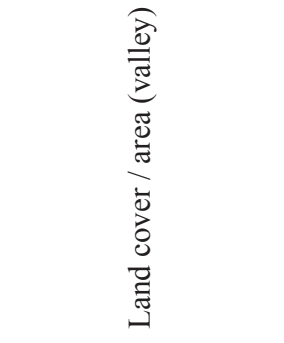 & $\begin{array}{l}\frac{\pi}{4} \\
\frac{\pi}{0} \\
0 \\
\frac{0}{0} \\
\frac{\pi}{0} \\
0 \\
\tilde{0}\end{array}$ & 莡 & 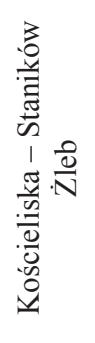 & 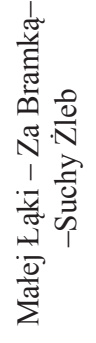 & 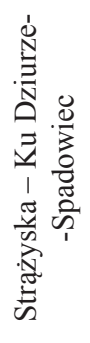 & $\frac{8}{80}$ & 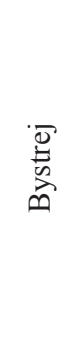 & 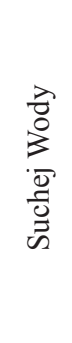 & $\frac{\frac{\pi}{4}}{\hat{N}_{0}^{0}}$ & 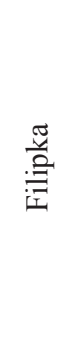 & 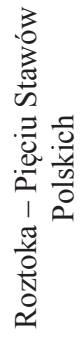 & 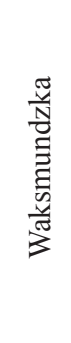 & 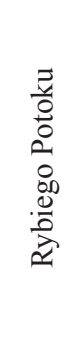 & 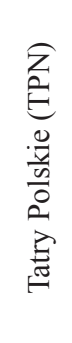 \\
\hline Forests & 42.2 & 58.2 & 31.6 & 58.0 & 70.5 & 76.1 & 45.6 & 34.3 & 55.5 & 76.5 & 12.3 & 34.9 & 37.0 & 42.5 \\
\hline Dwarf mountain pine & 8.5 & 0.2 & 9.5 & 1.7 & 1.1 & 1.5 & 15.4 & 13.9 & 1.0 & 0.0 & 18.3 & 18.3 & 9.3 & 9.2 \\
\hline Other & 35.9 & 13.9 & 37.4 & 28.3 & 14.7 & 11.0 & 30.5 & 30.4 & 8.1 & 3.1 & 66.2 & 39.7 & 31.5 & 30.7 \\
\hline Bark beetle & 4.4 & 6.9 & 13.7 & 7.6 & 8.5 & 10.3 & 5.9 & 13.0 & 16.3 & 3.6 & 3.1 & 6.3 & 12.3 & 9.1 \\
\hline Windfall & 2.8 & 14.7 & 5.2 & 3.1 & 5.1 & 0.8 & 0.8 & 0.2 & 2.1 & 0.2 & 0.0 & 0.0 & 0.2 & 2.3 \\
\hline $\begin{array}{l}\text { Deforestration of } \\
\text { mixed genesis }\end{array}$ & 6.3 & 6.0 & 2.6 & 1.2 & 0.0 & 0.2 & 1.8 & 8.3 & 17.0 & 16.5 & 0.0 & 0.9 & 9.6 & 6.2 \\
\hline
\end{tabular}


ization of hydrochemical environments of the Polish Tatras (Żelazny, 2015). In the Polish Tatras, calcium usually has the highest concentration among cations, while among anions - bicarbonate. Depending on lithological conditions in the waters of spring draining sedimentary rocks (mainly dolomites and limestone), calcium concentrations are higher than in crystalline areas. An increased concentration of magnesium ions in waters that drain the slopes made of dolomites is also observed. Among the anions, sulphate is the secondary ion, further are nitrates, before chlorides. The following is the dominant sequence of median ion concentrations typical for the Tatra Mountains: $\mathrm{HCO}_{3}-\mathrm{SO}_{4}-\mathrm{NO}_{3}-\mathrm{Cl}-\mathrm{Ca}-\mathrm{Mg}-\mathrm{Na}-\mathrm{K}$. In spring water draining the High Tatra granitoids, in the ion sequence, a higher concentration of sodium and potassium than magnesium is observed: $\mathrm{HCO}_{3}-\mathrm{SO}_{4}-\mathrm{NO}_{3}-\mathrm{Cl}-\mathrm{F}-\mathrm{Ca}-$ $\mathrm{Na}-\mathrm{K}-\mathrm{Mg}$, while in spring water draining granitoids in Goryczkowa in the Western Tatras: $\mathrm{HCO}_{3}-\mathrm{SO}_{4}-$ $\mathrm{NO}_{3}-\mathrm{Cl}-\mathrm{F}-\mathrm{Ca}-\mathrm{Na}-\mathrm{Mg}-\mathrm{K}$. In the shallow groundwater of the Carpathians, $\mathrm{HCO}_{3}^{-}$is the dominant ion among anions and $\mathrm{Ca}^{2+}$ among cations, which is confirmed by numerous studies of both surface waters and groundwater (e.g. Bombówna, 1969; Maultz, 1972; Welc, 1985; Drużkowski and Szczepanowicz; 1988; Żelazny (ed.) 2005, Wójcik, 2012; Siwek, 2012; Sajdak et al., 2018; Żelazny et al., 2018). A unique hydrogeochemical environment in the Western Carpathians has been described by Kosmowska et al. (2018), in the near-ridge part of the slope in the Malinowski Potok catchment in the Skrzyczne Massif, where the sequence of anions is as follows: $\mathrm{SO}_{4}-\mathrm{NO}_{3}-\mathrm{HCO}_{3}-\mathrm{Cl}$. They showed that the primary importance of sulfates is an effect of many years of anthropogenic pressure associated with depositing wet and dry sulfate from the urbanized areas of Upper Silesia and Cieszyn Silesia, the high secondary position of $\mathrm{NO}_{3}^{-}$results from the deforestation of the slopes, while $\mathrm{HCO}_{3}^{-}$was relatively of little importance.

Research conducted in the Tatras registered $1.76 \mathrm{mg} \cdot \mathrm{dm}^{-3}$ of $\mathrm{NO}_{3}^{-}$concentration expressed in the median in the first period (2007-2009), whilst in 2018 the concentration was as much as $60.2 \%$ higher $-2.82 \mathrm{mg} \cdot \mathrm{dm}^{-3}$ (see: Table 2). During this decade, deforestation in the lower and higher montane zone of the Polish Tatras caused a strong increase in $\mathrm{NO}_{3}^{-}$in the entire waters population which, is confirmed by positional statistics, e.g. $Q_{25 \%}$ increase by: $44.1 \%, Q_{75 \%}$ - $78.1 \%$, and $\mathrm{P}_{90 \%}-82.8 \%$. There was also a multiple increase in the maximum concentration from $7.72 \mathrm{mg} \cdot \mathrm{dm}^{-3}(2007-2009)$ to $21.30 \mathrm{mg} \cdot \mathrm{dm}^{-3}$ (2018). In the 2007-2009 period, the spatial differentiation of $\mathrm{NO}_{3}^{-}$according to the adopted scale of variation was small ( $\Psi=79.0 \%)$. After a decade (2018), it increased to a degree considered as average $(\Psi=102.3 \%)$.

It should be mentioned that in other regions of Poland in waters free of strong anthropopression induced by the agricultural use of the catchment or an increase in urbanization, the concentration of $\mathrm{NO}_{3}^{-}$is slightly lower than in the waters of TPN springs. Spatial differentiation of $\mathrm{NO}_{3}^{-}$expressed as a median in the Bieszczady Mountains in the Połonina Wetlińska massif according to the research of Kisiel et al. (2018) varied from $\sim 1$ to $\sim 2.75 \mathrm{mg} \cdot \mathrm{dm}^{-3}$. In the upper Parsęta drainage basin in the Kłuda, Valley Szpikowska and Szpikowski (2012) demonstrated that the highest average $\mathrm{NO}_{3}^{-}$concentration was in groundwater at the slope $-3.07 \mathrm{mg} \cdot \mathrm{dm}^{-3}$, while lower concentrations were recorded in drainage ditches $\left(1-2 \mathrm{mg} \cdot \mathrm{dm}^{-3}\right)$. Jachniak et al. (2019) noticed that the maximum con-

Table 2. Change in $\mathrm{NO}_{3}^{-}$concentration in waters in 2007-2009 and 2018.

\begin{tabular}{|c|c|c|c|c|c|c|c|c|}
\hline \multirow{2}{*}{ Parameter } & $\mathrm{P}_{10 \%}$ & $\mathrm{Q}_{25 \%}$ & $\mathrm{Me}$ & Avn. & $\mathrm{Q}_{75 \%}$ & $\mathrm{P}_{90 \%}$ & Max & $\Psi$ \\
\hline & \multicolumn{7}{|c|}{$\left[\mathrm{mg} \cdot \mathrm{dm}^{-3}\right]$} & {$[\%]$} \\
\hline $\mathrm{NO}_{3}^{-}$2007-09 & 0.66 & 1.15 & 1.76 & 1.92 & 2.54 & 3.41 & 7.72 & $79.0 \%$ \\
\hline $\mathrm{NO}_{32018}^{-}$ & 0.90 & 1.65 & 2.82 & 3.33 & 4.53 & 6.24 & 21.30 & $102.3 \%$ \\
\hline Difference & 0.24 & 0.51 & 1.06 & 1.41 & 1.99 & 2.82 & 13.58 & \\
\hline Increase [\%] & $36.8 \%$ & $44.1 \%$ & $60.2 \%$ & $73.4 \%$ & $78.1 \%$ & $82.8 \%$ & $175.9 \%$ & \\
\hline
\end{tabular}


centration of $\mathrm{NO}_{3}^{-}$in the valley of the Wapienica River in the western Carpathians, draining seminatural forested slopes of Klimczok, is $5.1 \mathrm{mg} \cdot \mathrm{dm}^{-3}$. Żelazny (2012) and Żelazny et al. (2013) from the pre-windfall period indicate that the concentration of $\mathrm{NO}_{3}^{-}$in waters draining the currently deforested slopes was lower (see: Table 4). Against the background of these studies, natural deforestation in the Tatras due to windfall (23-25 December 2013) was exceptional, because in the Kopki Kościeliskie area in the Kościeliska Valley over $90 \%$ of slopes suffered deforestation, e.g. in the Pośrednia Kopka catchement. Through triple surveys of the slopes of the Kościeliska Valley Żelazny et al. (2017) showed that in the summer half-year of 2015, waters draining slopes in both circumstances: after windfall and covered with forest damaged by bark beetles differ from waters flowing down the wooded slopes above all by a much higher concentration of $\mathrm{NO}_{3}^{-}$. The average concentration of $\mathrm{NO}_{3}^{-}$in waters draining deforested slopes after the windfall is $15.44 \mathrm{mg} \cdot \mathrm{dm}^{-3}$, at slopes with forest suffering from bark beetle gradation is $6,17 \mathrm{mg} \cdot \mathrm{dm}^{-3}$, and slopes covered by forest $-3,26 \mathrm{mg} \cdot \mathrm{dm}^{-3}$. It is worth noting that Kosmowska et al. (2015) in Carpathians in nearridge partial catchments on the slopes of the Silesian Beskids recorded multiple times lower $\mathrm{NO}_{3}^{-}$concentration in a catchment completely deforested due to long-lasting anthropopressure $-4.52 \mathrm{mg} \cdot \mathrm{dm}^{-3}$, while in catchment forested in $92 \%$ concentration was higher by $1 \mathrm{mg} \cdot \mathrm{dm}^{-3}$. In the Malinowski Potok basin $(68 \%$ afforestation) the average concentration of nitrates was $4.68 \mathrm{mg} \cdot \mathrm{dm}^{-3}$. Małek and Gawęda (2006) in the experimental forest catchment of the Potok Dupniański, located in the Stożek range in the Silesian Beskids, showed that the average concentration of $\mathrm{NO}_{3}^{-}$during low, medium and high hydration of the massif from all micro-catchments is $2.17 \mathrm{mg} \cdot \mathrm{dm}^{-3}$ and varies from $0.19 \mathrm{mg} \cdot \mathrm{dm}^{-3}$ to $4.45 \mathrm{mg} \cdot \mathrm{dm}^{-3}$. In the agro-forest catchments of the Miłoszówka and Chechło rivers, located in the Małopolska Upland, Bogdał et al. (2019) noticed low average $\mathrm{NO}_{3}^{-}$concentration ranging from $1.19 \mathrm{mg} \cdot \mathrm{dm}^{-3}$ (Chechło P4) to $5.13 \mathrm{mg} \cdot \mathrm{dm}^{-3}$ (Miłoszówka P1). According to the authors, multiple times higher concentration of $\mathrm{NO}_{3}^{-}$in the Miłoszówka catchment was caused by its high urbanization in the central part of the valley and greater anthropogenic pressure associated with land cultivation. Dąbrowska et al.
(2016) in an intensively used for agriculture basin of Strzegomka, where the use of nitrogen fertilizers doubled in 15 years, now it is as high as $\sim 135 \mathrm{~kg} \cdot \mathrm{ha}^{-1}$ proven that the $\mathrm{NO}_{3}^{-}$concentration in summer amounted to $18.81 \mathrm{mg} \cdot \mathrm{dm}^{-3}$.

Spatial differentiation of nitrate concentration is presented in Tab. 3 and in Fig. 2 in relation to 13 basic areas. A comparative analysis of $\mathrm{NO}_{3}^{-}$expressed in $\mathrm{P}_{90 \%}$ indicates that in 2018 their increase in relation to 2007-09 was recorded in 11 of 13 areas. $\mathrm{NO}_{3}^{-}$concentration increased over twice in the Bystra (123.2\%) and Lejowa (110.8\%) valleys. Lower $\mathrm{NO}_{3}^{-}$concentration in 2018 than in 2007-09 were recorded only in the Roztoka Valley together with the Pięć Stawów Polskich Valley $(-16.7 \%)$ and in the Waksmundzka Valley $(-18.0 \%)$. Spatial differentiation of the maximum concentrations of $\mathrm{NO}_{3}^{-}$is even more evident. Over twofold increase in maximum concentration of $\mathrm{NO}_{3}^{-}$was recorded in five valleys. A much higher value (see: Table 3) was recorded in the Lejowa Valley (by $348.2 \%$ ) with an increase from $4.75 \mathrm{mg} \cdot \mathrm{dm}^{-3}$ (2007-09) to $21.30 \mathrm{mg} \cdot \mathrm{dm}^{-3}$ (2018). An increase in $\mathrm{NO}_{3}^{-}$by far exceeding twofold was observed in the area of the Małej Łąki Valley, Za Bramką, Suchy Żleb, Kościeliska Valley, Staników Żleb, Strążyska Valley, $\mathrm{Ku}$ Dziurze, Spadowiec and Olczyska Valley. In other valleys, the increase was smaller. Only in the valleys of Rybi Potok, Waksmundzka, Roztoka and the Pięć Stawów Polskich the maximum concentration of $\mathrm{NO}_{3}^{-}$ was lower than in 2007-09. Generally, in 2018, 32 waters had higher $\mathrm{NO}_{3}^{-}$concentration than the highest value recorded a decade earlier (see: Fig. 2). Analysis of the range of high concentrations represented by $\mathrm{P}_{90 \%}$ and their maximum values clearly shows the mosaic character of these increases. Higher concentration values are observed in springs that drain the areas deforested by diverse causes. Few exceptions should be considered for individual maintenance areas. The highest concentrations of $\mathrm{NO}_{3}^{-}$occur in waters taken from slopes completely deforested by windfall. The concentration increases less in the waters that drain the forested slopes decaying because of bark beetle gradation. Generally, in regard to the entire Polish Tatras, the largest diversity of $\mathrm{NO}_{3}^{-}$occurs in the springs, which chemical composition are shaped by areas suffering a trees deterioration due to bark beetle gradation (see: Table 4). These can be estimated as average 
Żelazny, M., Pufelska, M., Sajdak, M., Jelonkiewicz, Ł., Bukowski, M. (2019). Effect of deforestation of different genesis on spatial variability... Acta Sci. Pol., Formatio Circumiectus, 18 (3), 149-161. DOI: http://dx.doi.org/10.15576/ASP.FC/2019.18.3.146

Table 3. Differentiation of $\mathrm{NO}_{3}^{-}$concentrations in 2007-2009 and 2018 in relation to valleys

\begin{tabular}{|c|c|c|c|c|c|c|c|c|c|c|c|c|c|c|}
\hline 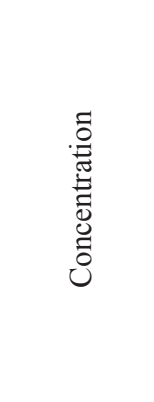 & 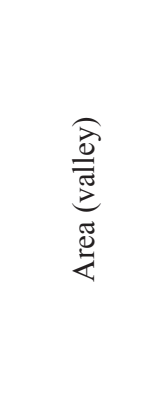 & 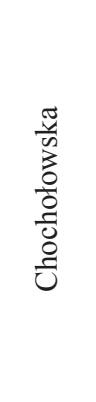 & $\frac{\pi}{3}$ & 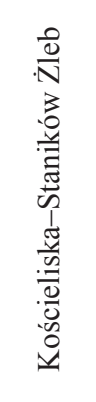 & 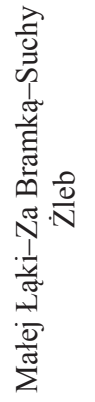 & 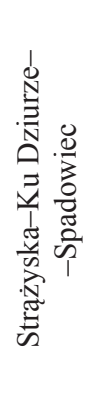 & $\begin{array}{l}8 \\
\frac{0}{0} \\
\frac{0}{\pi} \\
\frac{\pi}{n}\end{array}$ & 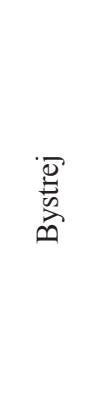 & $\frac{\frac{\pi}{\tilde{v}}}{\stackrel{N}{0}}$ & $\begin{array}{l}\overrightarrow{8} \\
0 \\
0 \\
\overline{0} \\
0 \\
0\end{array}$ & $\frac{\widetilde{g}}{\stackrel{\Xi}{\Xi}}$ & 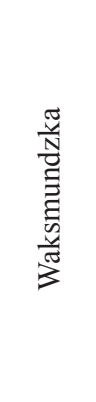 & 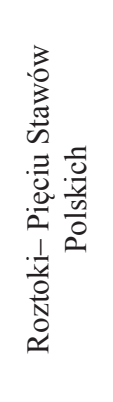 & 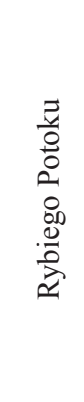 \\
\hline $\mathrm{Avr}_{2007-09}$ & & 1.62 & 2.68 & 2.20 & 2.79 & 2.39 & 3.05 & 1.66 & 2.05 & 1.76 & 2.21 & 1.22 & 1.45 & 1.23 \\
\hline $\operatorname{Avr}_{2018}$ & {$\left[\mathrm{mg} \cdot \mathrm{dm}^{-3}\right]$} & 2.92 & 4.69 & 4.20 & 4.71 & 3.81 & 3.89 & 2.65 & 3.37 & 2.25 & 2.52 & 0.94 & 1.17 & 1.38 \\
\hline Difference & & 1.30 & 2.01 & 2.00 & 1.91 & 1.42 & 0.84 & 0.99 & 1.32 & 0.49 & 0.31 & -0.28 & -0.28 & 0.15 \\
\hline Increase & {$[\%]$} & 80.4 & 74.9 & 90.9 & 68.5 & 59.3 & 27.4 & 59.4 & 64.3 & 28.0 & 14.2 & -23.2 & -19.5 & 12.2 \\
\hline $\mathrm{Me}_{2007-09}$ & & 1.29 & 2.74 & 1.87 & 2.51 & 2.44 & 3.04 & 1.58 & 1.85 & 1.74 & 2.01 & 1.18 & 1.41 & 1.23 \\
\hline $\mathrm{Me}_{2018}$ & {$\left[\mathrm{mg} \cdot \mathrm{dm}^{-3}\right]$} & 2.10 & 3.74 & 4.02 & 4.44 & 3.54 & 3.75 & 1.90 & 2.63 & 2.07 & 2.29 & 0.88 & 1.11 & 1.30 \\
\hline Difference & & 0.82 & 1.01 & 2.15 & 1.93 & 1.10 & 0.71 & 0.32 & 0.78 & 0.33 & 0.27 & -0.30 & -0.30 & 0.06 \\
\hline Increase & {$[\%]$} & 63.5 & 36.7 & 115.3 & 77.0 & 45.1 & 23.5 & 20.0 & 42.2 & 19.2 & 13.6 & -25.4 & -21.2 & 5.2 \\
\hline $\mathrm{P}_{90 \% 2007-09}$ & & 3.48 & 3.68 & 3.55 & 4.06 & 3.50 & 3.92 & 2.78 & 3.41 & 2.63 & 3.37 & 1.67 & 1.85 & 1.95 \\
\hline $\mathrm{P}_{90 \% 2018}$ & {$\left[\mathrm{mg} \cdot \mathrm{dm}^{-3}\right]$} & 6.15 & 7.75 & 6.61 & 6.54 & 6.42 & 5.87 & 6.20 & 4.74 & 3.71 & 4.88 & 1.37 & 1.54 & 2.24 \\
\hline Difference & & 2.67 & 4.07 & 3.06 & 2.49 & 2.92 & 1.94 & 3.42 & 1.32 & 1.08 & 1.51 & -0.30 & -0.31 & 0.29 \\
\hline Increase & {$[\%]$} & 76.8 & 110.8 & 86.3 & 61.3 & 83.2 & 49.6 & 123.2 & 38.8 & 41.0 & 44.9 & -18.0 & -16.7 & 14.9 \\
\hline $\operatorname{Max}_{2007-09}$ & & 7.72 & 4 & 6.24 & 4.57 & 3.81 & 4.50 & 4.91 & 6.38 & 3.18 & 4.74 & 1.74 & 3.88 & 3.23 \\
\hline $\operatorname{Max}_{2018}$ & $\left.\mathrm{ng} \cdot \mathrm{dm}^{-3}\right]$ & 11.04 & 21.30 & 15.12 & 11.30 & 9.15 & 8.70 & 8.71 & 12.93 & 4.68 & 8.41 & 1.60 & 1.90 & 3.04 \\
\hline Difference & & 3.32 & 16.54 & 8.88 & 6.73 & 5.34 & 4.20 & 3.80 & 6.55 & 1.50 & 3.67 & -0.14 & -1.99 & -0.18 \\
\hline Increase & {$[\%]$} & 43.0 & 348.2 & 142.3 & 147.3 & 140.2 & 93.3 & 77.4 & 102.7 & 47.2 & 77.4 & -8.0 & -51.20 & -5.6 \\
\hline
\end{tabular}

$\mathrm{NO}_{3}^{-}$concentrations which were limit values in Fig. 2 were bolded.

$\Psi=140.4 \%$. Overall, $\mathrm{NO}_{3}^{-}$concentration characteristics for land cover are (2018) at least twice as high as 10 years earlier. Repeated studies of Jasik et al. (2017) of several dozen springs in the Jaszcze forest basin in the Gorczański National Park have shown the impact of the species composition of the forest, its condition and hydration of the mountain massif on the average concentration of $\mathrm{NO}_{3}^{-}$. It has changed depending on the species composition of a forest. The lowest values were in the springs draining slopes covered with lower montane zone spruce $\left(1.90 \mathrm{mg} \cdot \mathrm{dm}^{-3}\right)$, meadows and pastures $\left(2.12 \mathrm{mg} \cdot \mathrm{dm}^{-3}\right)$, beech-fir trees $\left(2.62 \mathrm{mg} \cdot \mathrm{dm}^{-3}\right)$, multi-species with a predominance of spruce $\left(3.31 \mathrm{mg} \cdot \mathrm{dm}^{-3}\right)$, multi-species with a predominance of beech $\left(3.33 \mathrm{mg} \cdot \mathrm{dm}^{-3}\right)$. More than twice higher concentration were found in springs draining 


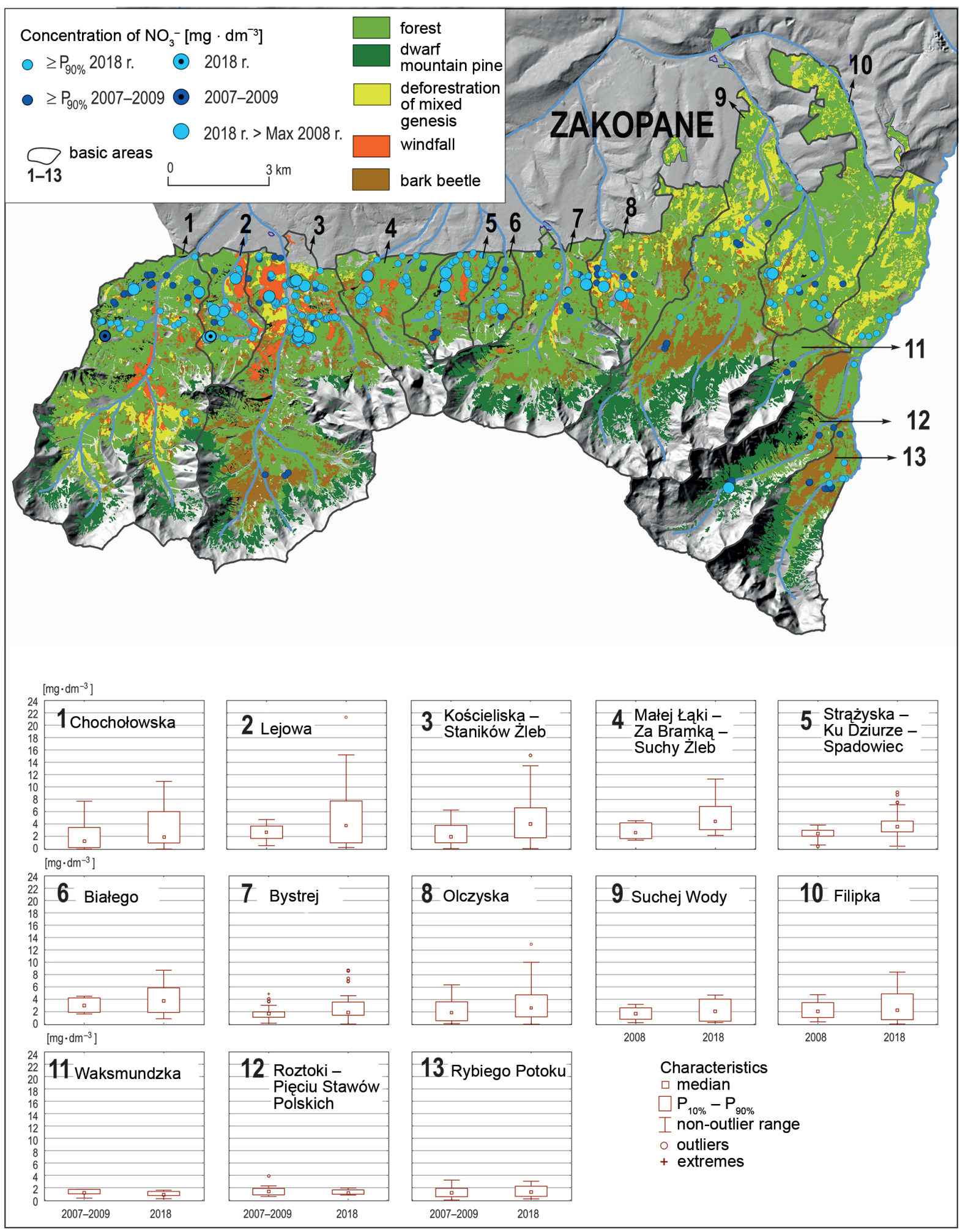

Fig. 2. Spatial diversity of $\mathrm{NO}_{3}^{-}$concentration in relation to valleys 
Żelazny, M., Pufelska, M., Sajdak, M., Jelonkiewicz, Ł., Bukowski, M. (2019). Effect of deforestation of different genesis on spatial variability... Acta Sci. Pol., Formatio Circumiectus, 18 (3), 149-161. DOI: http://dx.doi.org/10.15576/ASP.FC/2019.18.3.146

Table 4. $\mathrm{NO}_{3}^{-}$concentration characteristics $\left(\mathrm{mg} \cdot \mathrm{dm}^{-3}\right)$ in relation to land cover in 2007-2009 and 2018

\begin{tabular}{llllllllll}
\hline \multirow{2}{*}{ Research } & \multicolumn{1}{c}{ Land cover } & $\mathrm{P}_{10 \%}$ & $\mathrm{Q}_{25 \%}$ & Avr. & $\mathrm{Me}$ & $\mathrm{Q}_{75 \%}$ & $\mathrm{P}_{90 \%}$ & Max & $\Psi$ \\
\hline \multirow{3}{*}{$2007-09$} & Dwarf mountain pine & 0.31 & 0.68 & 1.01 & 1.06 & 1.35 & 1.64 & 1.89 & $63.3 \%$ \\
\cline { 2 - 10 } & Forests & 0.70 & 1.33 & 2.03 & 1.88 & 2.73 & 3.54 & 7.72 & $74.9 \%$ \\
\cline { 2 - 10 } & Bark beetle & 0.77 & 1.14 & 1.82 & 1.62 & 2.30 & 3.20 & 6.24 & $71.5 \%$ \\
\cline { 2 - 10 } & Windfall & 1.03 & 1.39 & 2.39 & 2.53 & 3.11 & 4.01 & 5.61 & $67.7 \%$ \\
\cline { 2 - 10 } & $\begin{array}{l}\text { Deforestation of } \\
\text { mixed genesis }\end{array}$ & 1.01 & 1.44 & 2.16 & 1.89 & 2.34 & 3.57 & 6.38 & $47.7 \%$ \\
\hline \multirow{3}{*}{2018} & Dwarf mountain pine & 0.63 & 0.79 & 0.98 & 0.90 & 1.18 & 1.45 & 1.95 & $43.4 \%$ \\
\hline & Forestes & 1.03 & 1.75 & 3.29 & 2.91 & 4.43 & 6.10 & 13.41 & $92.2 \%$ \\
\hline & Bark beetle & 1.08 & 1.73 & 4.09 & 3.21 & 6.24 & 7.93 & 15.12 & $140.4 \%$ \\
\hline
\end{tabular}

subalpine near-ridge parts of the slopes with a decaying beech and spruce trees $7.81 \mathrm{mg} \cdot \mathrm{dm}^{-3}$, and the highest in the higher montane zone spruce $11.98 \mathrm{mg} \cdot \mathrm{dm}^{-3}$. The wetness conditions had a significantly smaller impact on the differentiation of the average concentration of $\mathrm{NO}_{3}^{-}$, because it varied from $2.66 \mathrm{mg} \cdot \mathrm{dm}^{-3}$ during dry season to $5.43 \mathrm{mg} \cdot \mathrm{dm}^{-3}$ during wet season. In this context, the average concentration of nitrates in TPN springs in valleys with extensive deforestation of various genesis (e.g. bark beetle gradation, windfalls) is high, e.g. in the valleys: Małej Łąki - Za Bramką Suchy Żleb $\left(4.71 \mathrm{mg} \cdot \mathrm{dm}^{-3}\right)$, Lejowa $\left(4.69 \mathrm{mg} \cdot \mathrm{dm}^{-3}\right)$ or Kościeliska - Staników Żleb $\left(4.20 \mathrm{mg} \cdot \mathrm{dm}^{-3}\right)$. It should be emphasized that research carried out by Żelazny et al. (2017) shortly after deforestation of the Kopki Kościeliskie slopes in 2015 indicated that water from springs draining the completely deforested slopes of Kopki Kościeliskie had an average concentration of $15.44 \mathrm{mg} \cdot \mathrm{dm}^{-3}$, and $\mathrm{P}_{90 \%}$ read from the chart was $\sim 24 \mathrm{mg} \cdot \mathrm{dm}^{-3}$. This indicates a rapid, local, multiple increase in nitrate concentration in the slopes deforested by windfall.

It is worth to compare the concentration of $\mathrm{NO}_{3}^{-}$in the waters of the Polish Tatras with a typically agricultural region of Poland, e.g. Kujawy - an area characterized by very favourable natural conditions and intensive agricultural activity. In Kujawy, surface waters are particularly threatened by pollution with nitrogen compounds from agriculture. In the upper drainage basin of Zgłowiączka, in an area considered sensitive to pollution by nitrogen compounds from agricultural sources (OSN), Miatkowski and Smarzyńska (2014) recorded the maximum average nitrate concentrations from February to April, and their minimum concentration $<22.1 \mathrm{mg} \cdot \mathrm{dm}^{-3}$ in the summer months. In the agricultural catchment of Zagożdżonka near Radom, Kaznowska and Hejduk (2011) showed that the concentration of nitrates in 2008-2009 was definitely lower than in Kujawy and varied from $0.13 \mathrm{mg} \cdot \mathrm{dm}^{-3}$ (2009 IV) to $3.46 \mathrm{mg} \cdot \mathrm{dm}^{-3}$ (February, 2009), and the average concentration from low waters in 2008 $-0.49 \mathrm{mg} \cdot \mathrm{dm}^{-3}$. In the Sudół Dominikański agricultural catchment on the Proszowice Plateau, Kanownik and Rajda (2008) showed a higher concentration of nitrates than in the Zagożdżonka catchment and lower than in Kujawy, which totalled $10 \mathrm{mg} \cdot \mathrm{dm}^{-3}$ and increased from springs as the catchment area expands. With reference to Directive 91/676/EEC (1991), which specifies that above the concentration limit of $50 \mathrm{mg} \cdot \mathrm{dm}^{-3} \mathrm{NO}_{3}^{-}$(i.e. $11.3 \mathrm{mg} \cdot \mathrm{dm}^{-3} \mathrm{~N}_{\mathrm{NO} 3}$ ) surface water and groundwater is considered polluted, the maximum concentration recorded in TPN on deforested slopes $\mathrm{NO}_{3}^{-}\left(21.30 \mathrm{mg} \cdot \mathrm{dm}^{-3}\right)$ in 2018 is almost half of this value. If the nitrate concentration limit from the RMF (2002) was adopted regarding criteria for determining waters sensitive to nitrogen pollution 
from agricultural sources, where a concentration from 40 to $50 \mathrm{mg} \cdot \mathrm{dm}^{-3}$ was adopted for waters threatened by pollution, then the maximum value $\mathrm{NO}_{3}^{-}$in Tatra waters reached at least half of the limit value. It should be noticed, however, that if we assume $\mathrm{NO}_{3}^{-}$ $10 \mathrm{mg} \cdot \mathrm{dm}^{-3}$, above which eutrophication of surface waters is recognised (RMŚ 2002), then in the Tatra National Park it can be demonstrated that they are five valleys slopes where the maximum concentration is higher. More than twice as high $\mathrm{NO}_{3}^{-}$concentration occurred in the Lejowa Valley, whereas lower values were recorded in the valleys: Kościeliska - Staników Żleb, Olczyska, Małej Łąki - Za Bramką - Suchy Żleb and Chochołowska. During studies a decade earlier (2007-09), no concentration of $\mathrm{NO}_{3}^{-}$greater than $10 \mathrm{mg} \cdot \mathrm{dm}^{-3}$ was observed anywhere in TPN. The contemporary deterioration of the forest leads to a strong increase in $\mathrm{NO}_{3}^{-}$in waters and allows to identify adverse eutrophication phenomena caused by natural factors.

\section{SUMMARY AND CONCLUSIONS}

- In the period from 2007-09 to 2018 there was a rapid increase in the concentration of $\mathrm{NO}_{3}^{-}$in waters, connected with deforestation of the Tatra slopes.

- Contemporary $\mathrm{NO}_{3}^{-}$concentration in Tatra water samples has definitely proven its higher levels than in other regions of Poland in forested catchments or agricultural catchments, with the exception of catchments with intensive agricultural activities.

- Diverse causes of the deforestation (windfall, bark beetle gradation) result in a strong mosaic-like spatial differentiation of the $\mathrm{NO}_{3}^{-}$concentration.

- $\mathrm{NO}_{3}^{-}$concentration in waters draining the Tatra slopes that were deforested by windfall, exceeded the limit value of $10 \mathrm{mg} \cdot \mathrm{dm}^{-3}$, above which there may be an adverse eutrophication of waters, however, its causes in the Polish Tatras are natural.

* The work is a part of the project „Evaluation of the impact of large-area windfall on the hydrochemical regime and catchment denudation in mountain area forests (Polish Tatras)." financed from the Forest Fund of the State Forests National Forest Holding (ZP/483/2018; project UJ K/KDU/000494).

\section{REFERENCES}

Bogdał, A., Wałęga, A., Kowalik, T., Cupak, A. (2019). Assessment of the Impact of Forestry and SettlementForest Use of the Catchments on the Parameters of Surface Water Quality: Case Studies for Chechło Reservoir Catchment, Southern Poland. Water, 11, 964.

Bombówna, M. (1969). Hydrochemiczna charakterystyka rzeki Raby i jej dopływów. Acta Hydrobiologica, 11(4), 479-504.

Černý, J., Pačes, T. (1995). Acidification in the Black Triangle Region: Acid reign, 95, 5th International Conference on Acidic Deposition: Science and Policy, Göteborg, Sweden, 26-30 June 1995: Excursion, June 21-24, 1995, Czech Geological Survey, Prague.

Dąbrowska, J., Moryl, A., Kucharczak-Moryl, E., Żmuda, R., Lejcuś, I. (2016). Zawartość związków azotu w wodach rzeki Strzegomki powyżej zbiornika Dobromierz. Acta. Sci. Pol., Formatio Circumiectus, 15(3), 57-69.

Drużkowski, M., Szczepanowicz, B. (1988). Migracja pierwiastków w wodach powierzchniowych i opadach atmosferycznych na obszarze małej zlewni Pogórza Karpackiego. Folia Geographica, seria GeographicaPhisyca 20, 101-120.

Dyrektywa Parlamentu Europejskiego i Rady 91/676/EWG (1991). Dotyczy ochrony wód przed zanieczyszczeniami powodowanymi przez azotany pochodzące ze źródeł rolniczych, Dz.U. UE L z dnia 31 grudnia $1991 \mathrm{r}$.

Eshleman, K. N., Morgan, II R. P., Webb, J. R., Deviney, F. A., Galloway, J. N. (1998). Temporal patterns of nitrogen leakage from mid-Apallachian forested watersheds: role of insect defoliation. Water Resources Research, 34(8), 2005-2116.

Fabijanowski, J., Dziewolski, J. (1996). Gospodarka leśna. [in:] Z. Mirek, Z. Głowaciński, K. Klimek, H. PiękośMirkowa (ed.), Przyroda Tatrzańskiego Parku Narodowego, Tatry i Podtatrze 3, Tatrzański Park Narodowy, Kraków-Zakopane, 675-696.

Hess M.T. (1974). Piętra klimatyczne Tatr, Czasopismo Geograficzne, 45(1), 75-94.

Hornbeck, J.W. Martin, C.W., Pierce, R.S, Bormann, F.H, Likens, G.E, Eaton, J.S. (1987). The Northern hardwood forest ecosystem: ten years of recovery from clearcutting, NE-RP-596. Broomall, PA: U.S. Department of Agriculture, Forest Service, Northeastern Forest Experiment.

Hornbeck, J. W., Smith, C. T., Martin, Q. W., Tritton, L. M., Pierce, R. S. (1990). Effects of intensive harvesting on nutrient capitals of three forest types in New England. Forest Ecology and Management, 30 (1-4), 55-64. 
Żelazny, M., Pufelska, M., Sajdak, M., Jelonkiewicz, Ł., Bukowski, M. (2019). Effect of deforestation of different genesis on spatial variability... Acta Sci. Pol., Formatio Circumiectus, 18 (3), 149-161. DOI: http://dx.doi.org/10.15576/ASP.FC/2019.18.3.146

Houlton, B., Driscoll, C.T., Fahey, T.J., Likens, G.E., Groffman, P.M., Bernhardt, E. S., Buso, D.C. (2003). Nitrogen dynamics in ice storm-damaged forest ecosystems: implications for nitrogen limitation theory. Ecosystems, $6(5), 431-443$

Jachniak, E., Jaguś, A,. Młyniuk, A., Nycz, B. (2019). The Quality Problems of the Dammed Water in the Mountain Forest Catchment. Journal of Ecological Engineering, 20 (5), 165-171.

Jasik, M., Małek, S., Żelazny, M. (2017). Effect of water stage and tree stand composition on spatiotemporal differentiation of spring water chemistry draining Carpathian flysch slopes (Gorce Mts). Science of the Total Environment, 599-600, 1630-1637.

Kanownik, W., Rajda, W. (2008). Źródła zanieczyszczenia wód powierzchniowych w zlewni potoku Sudół Dominikański. Acta Scientiarum Polonorum Formacio Circumiectus, 7(2), 3-14.

Kaznowska, E., Hejduk, L. (2011). Ocena wybranych charakterystyk ilościowych i jakościowych okresów bezwezbraniowych w rzece Zagożdżonce. Przegląd Naukowy - Inżynieria i Kształtowanie Środowiska 52, 108-118.

Kisiel, M., Bochnak, D., Jastrzębska, B., Mostowik, K., Pufelska, M., Rzonca, B., Siwek, J. (2018). Skład chemiczny wód źródlanych w masywie Połoniny Wetlińskiej. Roczniki Bieszczadzkie, 26, 205-222.

Kosmowska, A., Żelazny, M., Małek, S., Siwek, J.P. (2015). Wpływ wylesień na krótkoterminowe zmiany składu chemicznego wody w zlewni Potoku Malinowskiego (Beskid Śląski). Sylwan, 159(9), 778-790.

Kosmowska, A., Żelazny, M., Małek, S., Stańczyk, T. (2018). Impact of deforestation on water chemistry in the western Tatras and Beskid Śląski range in the Polish Carpathians. Acta Sci. Pol., Formatio Circumiectus 18(3), 89-99.

Likens, G. E. (2013). Biogeochemistry of a Forested Ecosystem. New York: Springer.

Likens, G. E., Bormann, F. H., Johnson, N. M. (1969). Nitrification: importance to nutrient losses from a cutover forested ecosystem. Science, 163(3872), 1205-1206.

Małek, S., Gawęda, T. (2006). Charakterystyka chemiczna wód powierzchniowych zlewni Potok Dupniański w Beskidzie Śląskim. Sylwan, 150(2), 29-36.

Małek, S., Jasik, M., Durło, G. (2019). Jakość wody z ujęć zlokalizowanych w terenach leśnych zarządzanych przez Nadleśnictwo Myślenice. Sylwan, 163(4), 328-337.

Martin, C.W., Pierce, R.S., Likens, G.E., Bormann, F.H. (1986). Clearcutting affects stream chemistry in the White Mountains of New Hampshire. U.S. Department of Agriculture, Forest Service, Northeastern Forest Experiment Station, Broomall.
Maultz, S. (1972). Chemizm wód dopływów Górnej Wisły. Folia Geographica, Series Geographica-Physica, 6, 5-101.

Miatkowski, Z., Smarzyńska, K. (2014). Dynamika zmian stężenia związków azotu w wodach górnej Zgłowiączki w latach 1990-2011. Woda-Środowisko-Obszary Wiejskie, 14, 3(47), 99-111.

Murdoch, P. S., Stoddard, J. L. (1992). The role of nitrate in the acidification of streams in the Catskill Mountains of New York. Water Resources Research, 28(10), 2707-2720.

Pierzgalski, E., Janek, M., Kucharska, K., Tyszka, J., Wróbel, M. (2007). Badania hydrologiczne w leśnych zlewniach sudeckich. Synteza badań prowadzonych w latach 1993 -2005. Sękocin Stary: Instytut Badawczy Leśnictwa.

Pierzgalski, E., Janek, M., Kucharska, K., Niemtur, S., Stolarek, A., Tyszka, J., Wróbel, M. (2009). Procesy hydrologiczne i erozyjne w leśnych zlewniach górskich. Sękocin Stary: Instytut Badawczy Leśnictwa.

Radwańska-Paryska, Z. (1974). Roślinność tatrzańska. Czasopismo Geograficzne, 45(1), 47-62.

Rothe, A., Mellert, K.H. (2004). Effects of forest management on nitrate concentration in seepage water of forests in Southern Bavaria, Germany, Water, Air, and Soil Pollution, 156 (1-4), 337-355.

Rozporządzenie Ministra Środowiska z dnia 23 grudnia 2002 r. w sprawie kryteriów wyznaczania wód wrażliwych na zanieczyszczenie związkami azotu ze źródeł rolniczych. Dz.U. z 2002 r., 241, poz. 2093.

Sajdak, M., Siwek, J., Bojarczuk, A., Żelazny, M. (2018). Hydrological and chemical water regime in the catchments of Bystra and Sucha Woda. Acta Sci. Pol., Formatio Circumiectus, 17(3), 161-173.

Siemion, J., Burns, D. A., Murdoch, P. S., Germain, R. H. (2011). The relation of harvesting intensity to changes in soil, soil water, and stream chemistry in a northern hardwood forest, Catskill Mountains, USA. Forest Ecology and Management, 261(9), 1510-1519.

Siwek, J. (2012). Naturalne i antropogeniczne uwarunkowania zmienności chemizmu wód powierzchniowych w małych zlewniach na progu Pogórza Wiśnickiego. Kraków: Instytut Geografii i Gospodarki Przestrzennej UJ.

Strzyżowski, D., Fidelus, J., Żelazny, M. (2016). Geomorphological changes within a hillslope caused by a windthrow event in the Tatra Mountains, Southern Poland. Geografiska Annaler: Series A, Physical Geography, 98, 347-360.

Strzyżowski, D., Fidelus-Orzechowska, J., Żelazny M. (2018). Sediment transport by uprooting in the forested part of the Tatra Mountains, southern Poland. Catena, 160, 329-338. 
Stupnicka, E. (1997). Geologia regionalna Polski. Warszawa: Wyd. UW.

Swank, W.T., Swift, Jr. L.W., Douglass, J.E. (1988). Streamflow changes associated with forest cutting, species conversions, and natural disturbances, [in:] W.T. Swank, D.A. Crossley Jr., (eds.), Forest Hydrology and Ecology at Coweeta, Ecological Studies, 66, 297-312.

Swank, W. T., Vose, J. M. (1997). Long-term nitrogen dynamics of Coweeta forested watersheds in the southeastern United States of America. Global Biogeochemical Cycles, 11 (4), 657-671.

Szpikowska, G., Szpikowski, J. (2012). Właściwości fizykochemiczne wód rozlewisk bobrowych w Dolinie Kłudy (górna Parsęta) (Physicochemical properties of beaver wetlands water in the Kłuda Valley). Monitoring Środowiska Przyrodniczego, 13, 95-102.

Wang, X., Burns, D. A., Yanai, R. D., Briggs, R. D., Germain, R. H. (2006). Changes in stream chemistry and nutrient export following a partial harvest in the Catskill Mountains, New York, USA. Forest Ecology and Management, 223 (1-3), 103-112.

Welc, A. (1985). Zmienność denudacji chemicznej w Karpatach fliszowych (na przykładzie zlewni potoku Bystrzanka). Dokumentacja Geograficzna, 5.

Wójcik, S. (2012). Zróżnicowanie i sezonowa zmienność chemizmu wybranych źródeł zlewni potoku Olczyskiego w Tatrach, Prace Geograficzne, Instytut Geografii i Gospodarki Przestrzennej UJ, 128, 61-75.

Żelazny, M. (ed.) (2005). Dynamika związków biogennych w wodach opadowych, powierzchniowych i podziemnych w zlewniach o różnym użytkowaniu na Pogórzu Wiśnickim. Kraków: Instytut Geografii i Gospodarki Przestrzennej UJ.
Żelazny, M. (2012). Czasowo-przestrzenna zmienność cech fizykochemicznych wód Tatrzańskiego Parku Narodowego. Kraków: Instytut Geografii i Gospodarki Przestrzennej UJ.

Żelazny, M. (2015). Środowisko hydrogeochemiczne Tatr Polskich. Skala 1:250 000. [In:] K. Dąbrowska, M. Guzik (eds.), Atlas Tatr: przyroda nieożywiona. Cz. III.5. Skład chemiczny wód. Zakopane: Tatrzański Park Narodowy.

Żelazny, M., Adamska, M., Ciemborowicz, M., FidelusOrzechowska, J., Gus, M., Jaśkowiec, B., Jelonkiewicz, E., Jelonkiewicz, Ł., Karcz, T., Kolerski, T., Kosmowska, A., Kowalski, A., Lelito, M., Lisowicz, M., Michno, A., Płonka, K., Pufelska, M., Rajwa-Kuligiewicz, R., Rutkowska, A., Siwek, J.P., Siwek, J., Sajdak, M., Sobucki, M., Skaszczyk, A., Stańczyk, T., Stolarczyk, M., Stopka-Walkosz, M., Strzyżowski, D., Szubert, P., Wasak, K., Wrońska-Wałach, D. (2018). Ocena wpływu wielkoobszarowych wiatrołomów na reżim hydrochemiczny i denudację zlewni położonych w obszarach leśnych na terenach górskich (Tatry Polskie) - kontynuacja z modyfikacją. Kraków: Instytut Geografii i Gospodarki Przestrzennej UJ. www.tpn.nauka.raporty

Żelazny, M., Siwek, J.P., Fidelus, J., Stańczyk, T., Siwek, J., Rutkowska, A., Kruk, P., Wolanin, A., Jelonkiewicz, Ł. (2017). Wpływ wiatrołomu i degradacji drzewostanu na zróżnicowanie chemizmu wód w zlewni Potoku Kościeliskiego w obszarze Tatrzańskiego Parku Narodowego. Sylwan, 161 (1), 27-33.

Żelazny, M., Wolanin, A., Płaczkowska, E. (2013). Hypsometric factors for differences in chemical composition of Tatra National Park spring waters. Polish Journal of Environmental Studies, 22(1), 289-299.

\section{WPŁYW ROZPADU DRZEWOSTANU W TATRZAŃSKIM PARKU NARODOWYM NA ZRÓŻNICOWANIE PRZESTRZENNE STĘŻENIA AZOTANÓW}

\section{ABSTRAKT}

\section{Cel pracy}

Celem badań było określenie wpływu rozpadu drzewostanu różnej genezy na zróżnicowanie przestrzenne stężenia $\mathrm{NO}_{3}^{-}$w Tatrach Polskich.

\section{Materiat i metody}

W 2018 r. w Tatrach metodą kartowania hydrologiczno-chemicznego pobrano 728 wód. W laboratorium Hydrologiczno-Chemicznym IGiGP UJ metodą chromatografii jonowej oznaczono: $\mathrm{Ca}^{2+}, \mathrm{Mg}^{2+}, \mathrm{Na}^{+}, \mathrm{K}^{+}, \mathrm{HCO}_{3}^{-}$, $\mathrm{SO}_{4}^{-}, \mathrm{Cl}^{-}, \mathrm{NO}_{3}^{-}, \mathrm{NO}_{2}^{-}, \mathrm{NH}_{4}^{+}, \mathrm{PO}_{4}^{3-}, \mathrm{Li}^{+}, \mathrm{F}^{-}, \mathrm{Br}^{-}$. Do interpretacji wykorzystano azotany z 1719 wód, ponieważ ich obecne stężenie porównano do lat 2007-09 ( $n=991$ wód). Tatry podzielono na 13 obszarów. 


\section{Wyniki i wnioski}

Skład chemiczny wód drenujących zalesione oraz wylesione stoki tatrzańskie wykazał, że w dekadzie od 2007-09 do 2018 gwałtownie wzrosło stężenie $\mathrm{NO}_{3}^{-}$. W 2018 r. przeciętne stężenie $\mathrm{NO}_{3}^{-}$wyrażone medianą było wyższe aż o $60,2 \%$, wzrosło z 1,76 do $2,82 \mathrm{mg} \cdot \mathrm{dm}^{-3}$. Silniej uwidoczniło się zróżnicowanie maksymalnych stężeń, ponieważ ich wielokrotny wzrost wystąpił w pięciu dolinach największym w dolinie Lejowej (o 348,2\%) z 4,75 do 21,30 mg · dm³ bie; Kościeliskiej ze Stanikowym Żlebem; Strążyskiej, Ku Dziurze i Spadowcu i Olczyskiej. Tylko w dwóch obszarach występowały niższe stężenia. Porównując średnie stężenie $\mathrm{NO}_{3}^{-} \mathrm{w}$ wodach tatrzańskich wykazano, że są zdecydowanie wyższe niż w innych regionach Polski w zlewniach zalesionych lub w zlewniach rolniczych, z wyjątkiem zlewni z intensywną gospodarka rolną. Poligenetyczne przyczyny rozpadu drzewostanu skutkują silnym zróżnicowaniem przestrzennym stężenia $\mathrm{NO}_{3}^{-}$, które ma charakter mozaikowy. W wodach drenujących wylesione wskutek wiatrołomu stoki, występuje stężenie $\mathrm{NO}_{3}^{-}>10 \mathrm{mg} \cdot \mathrm{dm}^{-3}$, co potencjalnie może wywołać niekorzystne zjawisko eutrofizacji wód, jednak jego geneza ma naturalną przyczynę.

Słowa kluczowe: wody, Tatry, wylesienie, stężenie $\mathrm{NO}_{3}^{-}$, eutofizacja 